Jurnal Konstruksi Hukum | ISSN: 2746-5055

Vol. 2, No. 3, September 2021 Hal. 638-644| Tersedia online di https://www.ejournal.warmadewa.ac.id/index.php/jukonhum

DOI:http://doi.org/10.22225/jkh.2.3.3671.638-644

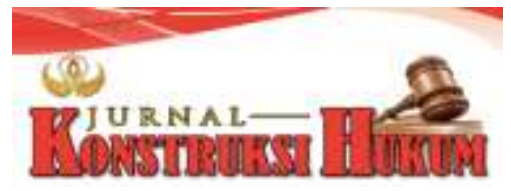

\title{
PEMANFAATAN SEMPADAN PANTAI KEDONGANAN OLEH PENGUSAHA CAFE BERDASARKAN PERDA KABUPATEN BADUNG NOMOR 26 TAHUN 2013
}

\author{
I Gede Yogi Arya Windiarta, Anak Agung Sagung Laksmi Dewi \\ Fakultas Hukum, Universitas Warmadewa, Denpasar - Bali, Indonesia \\ yogiwindiartaapple@gmail.com, laksmidewi@gmail.com \& putusuryani@gmail.com
}

\begin{abstract}
Abstrak
Rencana tata ruang yang diakomodir dalam suatu norma hukum baik pada tingkat pusat, provinsi begitu juga kota yang bersinergi satu sama lain. Tujuan dari penelitian ini yaitu untuk mengetahui pengaturan hukum dalam Perda RTRW Badung terhadap pemanfaatan sempadan pantai Kedonganan oleh pengusaha cafe dan sanksi apa yang dikenakan bagi pengusaha cafe tersebut jika melanggar Perda RTRW Badung. Untuk mencapai tujuan tersebut digunakan metode penelitian normatif dengan menggunakan pendekatan perundang-undangan dan pendekatan koseptual. Hasil penelitian yakni pengaturan mengenai pengusaha cafe yang mendirikan cafe di atas sempadan pantai Kedonganan diatur dalam Pasal 74 ayat (2) huruf d Peraturan Daerah Kabupaten Badung Nomor 26 Tahun 2013 bahwasanya dengan tidak mendirikan bangunan secara permanen di atas sempadan pantai tersebut. Selain itu juga harus rnernperhatikan kepentingan umum. Sanksi yang dapat dikenakan terhadap pengusaha cafe yang mendirikan cafe di atas sempadan pantai Kedonganan jika melanggar Peraturan Daerah Kabupaten Badung Nomor 26 Tahun 2013 diantaranya sanksi pidana yaitu Pasal 115 berupa pidana kurungan atau denda. Sanksi administratif berupa peringatan tertulis; penghentian sementara kegiatan: penghentian sementara pelayanan umum; penutupan usaha ; pencabutan izin; pembatalan izin; pembongkaran bangun-bangunan; pemulihan fungsi ruang; dan/atau denda administratif sebagaimana yang diatur dalam Pasal 112 ayat (2).
\end{abstract}

Kata kunci: Pengusaha Cafe, Pemanfaatan Sempadan Pantai, Penataan Ruang

\begin{abstract}
Spatial plans that are accommodated in a legal norm both at the central, provincial and city levels are in synergy with each other. The purpose of this study is to find out the legal arrangements in the Badung RTRW Regional Regulation on the use of the Kedonganan beach border by cafe entrepreneurs and what sanctions are imposed on the cafe entrepreneurs if they violate the Badung RTRW Regional Regulation. To achieve this goal, a normative research method is used using a statutory approach and a conceptual approach. The results of the study, namely the regulation of cafe entrepreneurs who set up cafes on the Kedonganan beach border, are regulated in Article 74 paragraph (2) letter $d$ of the Badung Regency Regulation Number 26 of 2013 that by not building permanently on the beach border. In addition, it must also pay attention to the public interest. Sanctions that can be imposed on cafe entrepreneurs who set up cafes on the Kedonganan beach border if they violate the Badung Regency Regulation Number 26 of 2013 include criminal sanctions, namely Article 115 in the form of imprisonment or fines. Administrative sanctions in the form of written warnings; temporary suspension of activities: temporary suspension of public services; business closure; license revocation; license cancellation; demolition of buildings; restoration of space functions; and/or administrative fines as regulated in Article 112 paragraph (2).
\end{abstract}

Keywords: Cafe Entrepreneur, Utilization of Coastal Borders, Spatial Planning

\section{PENDAHULUAN}

Rencana tata ruang yang diakomodir dalam suatu norma hukum baik pada tingkat pusat, provinsi begitu juga kota yang bersinergi satu sama lain. Tujuan pembentukannya tak lain untuk melindungi masyarakat dalam menggunakan ruang dari adanya penyalahgunaan ruang yang tidak mencerminkan keadilan. Bali khususnya yang terkenal dengan keindahan pantai, tak heran banyak pelaku usaha di bidang pariwisata yang memanfaatkan pantai sebagai daya tarik 
kelangsungan usahanya tersebut (Pemayun \& Sudiarta, 2019). Pemanfaatan demikian dilihat pada nyatanya di pantai Kedonganan. Bagian pantai Kedonganan yang digunakan yaitu sempadan pantai tersebut guna menunjang kegiatan usahanya yang dalam hal ini usaha cafe. Jika diperhatikan pemanfaatan sempadan pantai tersebut memberikan kesan seakan mengganggu akses publik dalam menikmati keindahan pantai Kedonganan. Fakta bahwa sempadan pantai bukanlah lahan yang diperuntukan untuk keperluan warga (Iswari et al., 2021). Ditelaah pada Pasal 28 Undang-Undang No. 26 Tahun 2007 yang berpokok pada pengaturan penataan ruang selanjutnya disebut UUPR, telah diatur di dalamnya bahwasanya penambahan dalam aspek penataan ruang dalam wilayah kota/kabupaten salah satunya menekankan pada penyediaan dan pemanfaatan terhadap ruang terbuka hijau. Dalam Pasal 29 ayat (1) UUPR menyatakan adanya dua bagian diantaranya ruang terbuka hijau dari segi publik dan privat. Ditinjau dari penjelasan Pasal tersebut, bahwasanya pantai termasuk kategori ruang terbuka hijau yang bersegi publik.

Penataan ruang bertujuan dalam hal tercapainya pemanfaatan sumber daya dengan optimal hingga semaksimal mungkin, hal demikian untuk menghindari akan terjadinya suatu konflik akibat dari pemanfaatan sumber daya mencegah timbulnya kerusakan lingkungan hidup dan mengedepankan keselarasan (Santosa, 2005). Penataan tata ruang juga bertujuan unutk menciptakan ruang yang berkualitas bagi masyarakat (Setyati \& Utomo, 2015). Penataan ruang memiliki suatu pengelompokan yang dilandasi atas sistem, administratif, fungsi kawasan, nilai stategis kawasan, dan kegiatan kawasan (Ridwan, Juniarso \& Sodik, 2008). Merujuk pada penataan ruang secara administratif terdapat pejabat yang diberikan tugas dan wewenang oleh undang-undang diantaranya Presiden, Gubernur, Bupati/Walikota, dan perangkat daerah yang didasari atas pendekatan wilayah secara administratif sebagaimana diatur dalam Pasal 7 UUPR.

Pemerintah Daerah khususnya di Provinsi Bali telah memperoleh tugas dan wewenang dalam rangka penataan ruang di wilayah hukumnya sebagaimana telah diatur dalam Peraturan Daerah Provinsi Bali No.3 Tahun 2020 yang bersubtansi mengenai perubahan atas Peraturan Daerah Provinsi Bali No.16 Tahun 2009 yang berpokok pada pengaturan penataan ruang di wilyah Provinsi Bali Tahun 2009 sampai 2029. Dalam pengaturan tersebut diatur pula mengenai pelimpahan wewenang dari pemerintah provinsi kepada pemerintah kabupaten/kota mengenai tugas dan wewenang dalam pentaan ruang. Pemerintah Kabupaten Badung telah mempunyai produk hukum dalam rangka penyelenggaraan penataan ruang sebagaimana diatur dalam Peraturan Daerah Kabupaten Badung No. 26 Tahun 2013 yang berpokok pada pengaturan tent ang rencana penataan ruang wilayah Kabupaten Badung tahun 2013 sampai dengan 2033 selanjut nya disebut PERDA RTRWK Badung.

Hal ini perlu diperhatikan untuk itu sudah banyak penelitian-penelitain terdahulu yang mengkaji mengenai persoalan ini. Misalnya pada penelitian Pribadi pengendalian pemanfaatan ruang sempadan pantai di Kecamatan Padang Barat Kota Padang. Pengendalian yang dilakukan adalah penetapan zonasi, perizinan, pemberian insentif dan disinsentif serta pengenaan sanksi (Pribadi, 2018). Pemanfaatan sepadan sungai juga tidak luput dari masyarakat atau oknum-oknum tidak bertanggung jawab. Untuk itu perlu penegakan hukum atas pelanggaran pemanfaatan sempadan pada sungai, pada kasus ini peneliti sebelumnya mengambil sample pada sungai di Kabupaten Sidoarjo (Dwi Prastiandiani, 2016). Penelitian selanjutnya, mengkaji pemanfaatan tanah di sempadan sungai menurut Undang-undang Nomor 5 Tahun 1960 Tentang Dasar PokokPokok Agraria dan Undang-Undang Nomor 26 Tahun 2007 Tentang Penataan Ruang (Nurlutfi, 2020). Kemudian, peneliti memutuskan untuk mengkaji pemanfaatan sempadan pantai dengan mengambil objek Pantai Kodangan di Badung, Bali berdasarkan Peraturan Daerah Badung Nomor 26 Tahun 2013. Tujuan dari penelitian ini yaitu untuk mengetahui pengaturan hukum dalam Perda RTRW Badung terhadap pemanfaatan sempadan pantai Kedonganan oleh pengusaha cafe dan sanksi apa yang dikenakan bagi pengusaha cafe tersebut jika melanggar Perda RTRW Badung.

\section{METODE PENELITIAN}

Dalam mendukung penelitian ini suatu metode penelitian merupakan hal yang penting. Metode penelitian yang dipakai dalam mendukung kajian ini adalah yuridis normatif. Dipilihnya 
demikian, dikarenakan materi tersebut fokus pada uraian permasalahan yang selanjutnya dikaji berdasarkan teori hukum serta dikorelasikan dengan peraturan perundang-undangan (Soekanto \& Mamudji, 2015). Di samping itu, penelitian ini juga didukung oleh beberapa pendekatan yang terdiri dari pendekatan peraturan perundang-undangan dan konseptual. 


\section{HASIL DAN PEMB AHASAN}

\section{Pengaturan Hukum terhadap Pengusaha yang Mendirikan Cafe di Sempadan Pantai Kedongan}

Indonesia yang memiliki jati diri sebagai negara hukum, menimbulkan konsekuensi bahwasanya wewenang yang diperoleh oleh pemerintah telah terlegitimasi dalam peraturan perundangundangan. Begitu juga dalam rangka penyelenggaraan penataan ruang di Indonesia, adanya beberapa peraturan perundang-undangan yang dijadikan pedoman dasar hukum. Indonesia disamping berjati diri negara hukum ju ga memiliki konsep negara kesejahteraan, yang termaksud dalam alinea keempat UUD NRI 1945, sebagaimana juga menimbulkan konsekuensi bahwasanya adanya campur tangan adrninistrasi negara dalam rangka memberikan suatu pelayanan terhadap masyarakat.

Menyinggung pada Pasal 33 ayat (3) UUD NRI 1945 bahwasanya bumi, air, termasuk juga kekayaan alam yang ada di dalamnya negaralah yang menguasai tersebut yang ditujukan untuk kemakmuran rakyatnya dengan sebesar-besarnya. Hal demikian sebagai landasan pacu terbentuknya produk hukum negara Indonesia dalam mengatur penataan ruang secara nasional melalui UUPR. Tata ruang pada hakikatnya memiliki tujuan dalam rangka pemanfaatan sumber daya yang optimal sehingga sedapat mungkin untuk menghindari timbulnya konflik serta kerusakan lingkungan hidup, dan upaya peningkatan keselarasan (Santosa, 2005). Ruang sejatinya harus dimanfaatkan secara bijaksana dan efisien, sebagaimana hal tersebut bertujuan agar pernanfaatan sumber daya alarn dilakukan secara optimal u ntuk kemakmuran rakyat dengan sebesar-besarnya. Jika ditelaah Pasal 1 angka 1 UUPR menegaskan bahwa:

"penataan ruang adalah wadah yang meliputi ruang darat, laut dan udara, termasuk juga ruang yang ada di dalam bumi sebagai satu kesatuan wilayah, tempat manusia maupun makhluk hidup lainnya, untuk hidup melakukan kegiatan serta memelihara kelangsungan hidupnya.“

Sebagaimana salah satu bagian pengelompokan penataan ruang yaitu adininistratif bahwasanya dilaksanakan oleh pemerintah baik pusat maupun daerah. Pemerintah Kabupaten Badung sendiri telah memiliki payung dalam mengejawantahkan penataan ruang di wilayahnya yaitu PERDA RTRWK Badung. Hal dernikian didasari pula karena Kabupaten Badung sebagai daerah yang pesat sehingga membutuhkan pedoman dalam hal pembangunan wilayah untuk mengantisipasi perkembangan 20 (dua puluh) tahun ke depan sebagaimana termaktu b dalam Penjelasan PERDA RTRWK Badung.

Merujuk pada substansi PERDA RTRWK Badung yang dalam hal bahasan ini adalah sempadan pantai, jika ditelaah pengenian dari sempadan pantai terdapat dalam Pasal I angka 33. Sebagaimana dinyatakan bahwa sempadan pantai merupakan kawasan perlindungan setempat sepanjang pantai tersebut memiliki kemanfaatan yang penting guna mempertahankan kelestarian dan kesucian pantai, ketersediaan ruang untuk lalu lintas umum, dan keselamatan bangunan. Kawasan dalam penataan ruang dibagi menjadi dua yaitu kawasan lindung dan budidaya. Khususnya kawasan lindung, ditinjau dari pengertiann ya telah diatur dalam Pasal 1 angka 24 PERDA RTRWK Badung, sebagaimana bahwa kawasan lindung adalah kawasan yang berdasarkan penetapan berfungsi utama untuk melindungi kelestarian lingkungan meliputi sumber daya alarn dan sumber daya buatan. Sempadan pantai termasuk dalam kawasan lindung dengan kategori kawasan perlindungan setempat sebagaimana diatur dalam Pasal 25 PERDA RTRW Badung. Terkait permasalahan yang dibahas mengenai penggunaan sernpadan pantai Kedongangan, secara yuridis pantai Kedongan telah ditugaskan sebagai sebaran kawasan senlpadan pantai di Kabupaten Badung yang tertuang dalam Pasal 28 ayat (2) huruf c PERDA RTRW K Badung. Kasus yang menjadi obyek pembahasan dalam penelitian ini yaitu pengusaha cafe yang rnelangsungkan kegiatan usahan ya di sempadan pantai Kedonganan. Jika ditinjau berdasarkan PERDA RTRWK Badung yaitu pada Pasal 56 ayat (3) bahwasanya penggunaan dan pemanfaatan tanah pada bidang-bidang tanah yang berada di sempadan pantai, sungai, maupun jurang harus rnemperhatikan kepentingan u mum, serta keterbatasan daya dukung, keterkaitan ekosistem, pembangunan berkelanjutan, dan keanekaragaman hayati serta kelestarian fungsi lingkungan itu sendiri. 
Dalam hal ini pengusaha cafe tentunya harus memperhatikan aspek kepentingan umum dalam penggunaan dan pemanfaatan tanah pada sempadan pantai. Jika dirujuk pada Pasal 74 ayat (1) PERDA RTRW Badung menentukan bahwa zonasi sempadan pantai dari segi jarak yaitu daratan sepanjang tepian laut dengan jarak minimal seratus meter dari titik pasang air laut tertinggi ke arah daratan. Kemudian dalam Pasal 74 ayat (2) huruf d PERDA RTRWK Badung yang juga menegaskan ketentuan umum zonasi sempadan pantai bahwasanya: "ruang kawasan sempadan pantai merupakan ruang terbuka untuk umum dan bangunan yang diperkenankan adalah bangunan-bangunan fasilitas penunjang wisata non permanen dan temporer." Dari pengaturan tersebut dapat disimpulkan bahwa pengaturan hukum terhadap pengusaha cafe yang mendirikan atau melangsungkan usaha cafenya diperkenankan asalkan memperhatikan kepentingan umum dan tidak rnendirikan bangunan secara permanen di atas sempadan pantai tersebut.

\section{Sanksi Hukum Bagi Pengusahan Cafe yang Melanggar PERDA Kabupaten Badung Peraturan Daerah Provinsi Bali No. 26 Tahun 2013 tentang Rencana Tata Ruang Wilayah}

Pengertian sanksi berdasarkan KBBI diartikan: tanggungan, untuk memaksa seseorang untuk menepati ketentuan undang-undang atau perjanjian; imbalan negatif berupa pembebanan (Kamus Besar Bahasa Indonesia, 1995: 1265). Menurut Samsul et al (2014), merujuk pada macam-macam sanksi diantaranya:

\section{Sanksi Pidana}

Sanksi pidana bersifat lebih tajam dibanding sanksi hukum lainn ya seperti sanksi perdata maupun sanksi administrasi. Sanksi pidana ditujukan untuk mencegah dan menanggulangi kejahatan. Hukum pidana rnemuat ketentuan sanksi yang akan dituju kan bagi pelanggar peraturan, sebagaimana sanksi tersebut berupa penambahan penderitaan dengan sengaja (Samsul et al., 2014). KUHP sebagai sumber hukum pidana Indonesia dijadikan sebagai acuan aturan secara umum dan juga undang-undang khusus lainnya di luar KUHP Pasal 10 KUHP mengatur mengenai jenis-jenis pidana diantaranya pidana pokok, diantaranya pidana mati, pidana penjara, pidana kurungan, pidana denda, pidana tutupan; Pidana tambahan, diantaranya pencabutan hakhak tertentu, perampasan barang-barang tertentu, serta pengumuman putusan hakim.

2. Sanksi Perdata

Sanksi perdata ditujukan bila ada pihak yang melanggar perjanjian atau undang-undang. Sanksi perdata dapat berupa pembayaran ganti kerugian atas hak sesorang yang telah dilanggar.

3. Sanksi Administrasi

Sanksi administrasi memiliki 4 (empat) unsur diantaranya yaitu alat kekuasaan, bersifat hukum publik, digunakan pemerintah sebagai reaksi terhadap ketidakpatuhan. Jenis-jenis sanksi yaitu:

- Sanksi reparatoir yaitu sanksi dengan tujuan untu k memulihkan keadaan seperti semula sebelu m pelanggaran terjadi. Contoh: bestuursdwang, dwangsom;

- Sanksi pinitif, yaitu sanksi yang bersifat menghukum berurna pembayaran denda administratif;

- Sanksi regresif, yaitu sanksi yang bertujuan sebagai wujud n yata dari ketidakpatuhan terhadap ketentuan (Ridwan, Juniarso \& Sodik, 2008)

Pelanggaran di bidang Penataan Ruang sebagaimana dimaksud dalam Pasal 100 ayat (2) PERDA RTRW Badung meliputi:

a. Ketidaksesuaian pemanfaatan ruang dengan Rencana Tata Ruang;

b. Ketidaksesuaian pemanfaatan ruang dengan UUPR yang diterbitkan oleh pejabat berwenang;

c. Ketidaksesuaian pemanfaatan ruang dengan persyratan izin yang telah diberikan oleh pejabat berwenang;

d. menghalangi akses kawasan yang ditentukan oleh peraturan perundang-undangan yang merupakan milik umum.

Dalam penegasan Pasal 108 PERDA RTRW Badung mengatur bahwa dalam kegiatan

Penataan Ruang W ilayah, setiap orang wajib untuk: 
a. Taat terhadap rencana Tata Ruang yang telah ditetapkan;

b. memanfaatkan ruang berdasarkan UUPR

c. Patuh terhadap ketentuan yang ditetapkan dalam UUPR

d. Memberi akses sumber air, pesisir pantai, termasuk kawasan yang srdinyatakan oleh perundang-undangan sebagai milik umum.

Mengenai sanksi administratif akan dikenakan jika ada pihak yang melanggar ketentuan sebagaimana yang telah diuraikan di atas. Pasal 112 ayat (1) menegaskan bahwa: "Setiap orang yang melanggar ketentuan sebagaimana dimaksud dalam Pasal 94 ayat (1), ayat (2), dan ayat (3), Pasal 100 ayat (2), dan Pasal 108 dikenai sanksi administratif." Sanksi administratif yang dimaksud sebagaimana diatur dalam Pasal 112 ayat (2) yaitu:

a.) peringatan tertulis;

b.) penghentian sementara pelayanan umum;

c.) penghentian sementara kegiatan;

d.) pencabutan izin;

e.) penutupan usaha;

f.) pembongkaran bangun-bangunan;

g.) pembatalan izin;

h.) pemulihan fungsi ruang;

i.) denda adrninistratif.

Merujuk pada sanksi pidana telah diatur dalam BAB XVII PERDA RTRW Badung. Pasal 115 ayat (1) menegaskan bahwa:

"Setiap orang yang rrielanggar ketentuan sebagaimana dimaksud dalam Pasal 94 ayat (2) dan ayat (3) serta Pasal 108, dipidana dengan pidana kurungan paling larna 6 (enam) bulan atau pidana denda paling banyak Rp.50.000.000,00 (lima puluh juta rupiah). "Tindak pidana ini digolongkan sebagai bentuk pelanggaran (Pasal 115 ayat (2)), selain ancaman pidana sebagaimana dimaksud pada Pasal di atas, dapat juga dikenai sanksi pidana sesuai peraturan perundang-undangan. Kemudian terdapat pula mengenai sanksi pidana yang dijatuhkan khusus pada pejabat pemerintah Pemerintah Kabupaten sebagaimana diatur dalam Pasal 116 PERDA RTRW Badung. Akan tetapi untuk mempersernpit pembahasan dalam sub bab ini tidak dijelaskan mengenai sanksi yang dimaksud. Karena memfokuskan pada pendiri cafe yang mendirikan cafe di atas sempadan pantai. Sanksi perdata dalam PERDA RTRW Badung ini hanya ditujukan pada pejabat Pemerintah Kabupaten Badung yang melakukan tindak pidana sebagaimana dimaksud dalam Pasal 116, yang dimana jika ada pihak yang merasa dirugikan atas tindak pidana tersebut dapat menuntut ganti kerugian secara perdata. Jadi dapat disimpulkan bahwa bagi pengusaha cafe yang mendirikan cafe di atas sempadan pantai Kedonganan yang tidak sesuai dengan pemanfaatan ruang dapat dikenakan sanksi administratif berupa sebagaimana yang diatur dalam Pasal 112 ayat (2) PERDA RTRW Badung dan dapat dikenakan sanksi pidana sebagaimana dimaksud dalam Pasal 115 PERDA RTRW Badung.

\section{SIMPULAN DAN SARAN}

\section{Simpulan}

Pengaturan mengenai pengusaha cafe yang mendirikan cafe di atas sempadan pantai Kedonganan diatur dalam Pasal 74 ayat f2) huruf d Peraturan Daerah Kabupaten Badung Nomor 26 Tahun 20 13 bahwasanya dengan tidak mendirikan bangunan secara perrnanen di atas sempadan pantai tersebut. Selain itu juga harus memperhatikan kepentingan umum. Sanksi yang dapat dikenakan terhadap pengusaha cafe yang mendirikan cafe di atas sempadan pantai Kedonganan jika melanggar Peraturan Daerah Kabupaten Badung Nomor 26 Tahun 2013 diantaranya sanksi pidana yaitu Pasal 115 berupa pidana kurungan atau denda. Sanksi adrninistratif berupa peringatan tertulis; penghentian sementara kegiatan; penghentian sementara pelayanan umum; penutupan usaha; pencabutan izin; pembatalan izin; pembongkaran bangun-bangunan; pemulihan fungsi ruang; dan/atau denda administratif sebagaimana yang diatur dalam Pasal 112 ayat (2). Sedangkan sanksi perdata berdasarkan Peraturan Daerah tersebut tidak ditujukan kepada pengusaha cafe tersebut akan tetapi ditujukan kepada pemerintah. 


\section{Saran}

Untuk itu, terdapat beberapa saran yang ditujukan bagi pendiri cafe yang sudah mendirikan atau yang akan mendirikan cafe di sempadan pantai Kedonganan sebaiknya mentaati PERDA RTRW Badung agar pemanfaatan ruang pada sempadan pantai dapat memberikan kelestarian lingkungan pantai dan mementingkan aspek kepentingan umum sebagai ruang publik. Sebaiknya pendiri cafe yang sudah mendirikan atau akan mendirikan cafe di sempadan pantai kedonganan menghindari terjadinya pelanggaran PERDA RTRW Badung, karena dapat berdampak pada kelangsungan usahanya. Untuk pemerintah sebaikn ya tetap melakukan tindakan tegas terhadap pengusaha cafe yang memanfaatkan sempadan pantai jika rnelanggar PERDA RTRW Badung.

\section{DAFTAR PUSTAKA}

Dwi Prastiandiani. (2016). Penegakan Hukum atas Pelanggaran Pemanfaatan Sempadan Sungai di Wilayah Kabupaten Sidoarjo. Jurnal Kebijakan \& Manajemen Publik, Vol.4(2).

Iswari, A. A. I. P. M., Puspadma, I. N. A., \& Suryani, L. P. (2021). Konsinyasi dalam Pengadaan Tanah Bagi Pembangunan Untuk Kepentingan Umum. Jurnal Konstruksi Hukum, Vol.2(2).

Nurlutfi, V. (2020). Analisis Yuridis Pemanfaatan Tanah di Semapadan Sungai Menurut Undang-Undang Nomor 5 Tahun 1960 Tentang Dasar Pokok-Pokok Agraria dan Undang-Undang Nomor 26 Tahun 2007 Tentang Penataan Ruang. Faculty of Law, Universitas Pelita Harapan.

Pemayun, C. I. S. P., \& Sudiarta, I. K. (2019). Kebijakan Pemerintah Provinsi Bali Terhadap Pengelolaan Sempadan Pantai Secara Privat Terkait Keadilan Bagi Publik dalam Perspektif Hukum Tata Ruang. Jurnal Ketha Negara, Vol.7(8).

Pribadi, T. (2018). Pengendalian Pemanfaatan Ruang Sempadan Pantai di Kecamatan Padang Barat Kota Padang. Fakultas Hukum. Universitas Andalas.

Ridwan, Juniarso \& Sodik, A. (2008). Hukum Tata Ruang dalam Konsep Kebijakan Otonomi Daerah. Nuansa, Bandung.

Samsul, Ramli, \& Fahrurrazi. (2014). Bacaan Wajib Swakelola Pengadaan Barang/Jasa Pemerintah. Visimedia, Jakarta.

Santosa, W. Y. (2005). Tarik ulur Pengelolaan Sumber Daya Alam dalam Era Otonomi Daerah: Kajian Terhadap Proyek Konservasi Kawasan Segara Anakan Cilacap. Mimbar Hukum, Vol.6(50).

Setyati, R., \& Utomo, W. (2015). Implementasi Kebijakan Penataan Ruang Terbuka Hjau Kawasan Perumahan Kota Banjarbaru. Jurnal Kebijakan Dan Administrasi Publik, Vol.19(1).

Soekanto, S., \& Mamudji, S. (2015). Penelitian Hukum Normatif Suatu Tinjauan Singkat. Rajawali Pers, Jakarta. 